\title{
Supervisi Edukatif Untuk Meningkatkan Kemampuan Guru dalam Pembelajaran di SD
}

\section{*Gusti Ayu Anom 1}

${ }^{1}$ SD Negeri 3 Banjar tegal

\section{A R T I C L E I N F O \\ Article history: \\ 1 Maret 2020 Received in revised form \\ 30 Maret 2020 \\ Accepted 11 April 2020 \\ Available online 15 \\ Mei 2020}

\section{Kata Kunci:}

supervisi edukatif

kemampuan guru

Keywords:

educational supervision

teacher competention

\begin{abstract}
A B S T R A K
Penelitian tindakan sekolah ini bertujuan untuk meningkatkan kemampuan guru SD dalam melaksanakan pembelajaran di kelas melalui penerapan supervisi edukatif. Penelitian ini dilaksanakan dalam 2 siklus, dan setiap siklus terdiri dari 4 tahap yaitu perencanaan, pelaksanaan, observasi/evaluasi dan refleksi. Berdasarkan hasil analisis data terlihat peningkatan kemampuan guru melaksanakan proses pembelajaran. Pada siklus prasiklus rata-rata kemampuan guru melaksanakan proses pembelajaran di kelas sebesar 67,08 dengan tingkat kemampuan guru sebesar $67,08 \%$ yang berada pada kategori cukup. Kemampuan guru dalam melaksanakan proses pembelajaran di kelas pada siklus I meningkat dengan rata-rata sebesar 70,52 dengan tingkat kemampuan guru sebesar $70,52 \%$ yang yang berada pada kategori cukup. Pada siklus II kemampuan guru dalam melaksanakan
\end{abstract} proses pembelajaran mengkat lagi 77,29 dengan tingkat kemampuan guru sebesar $77,29 \%$ yang berada pada kategori baik. Kemampuan guru dalam melaksanakan proses pembelajaran pada siklus II sudah melampaui indikator keberhasilan yaitu dengan tingkat kemampuan guru sebesar $75 \%$. Berdasarkan hal tersebut dapat disimpulkan bahwa penerapan supervisi edukatif dapat meningkatkan kemampuan guru SD Negeri 3 Banjar Tegal semester II tahun pelajaran 2019/2020 dalam pembelajaran di kelas.

\section{A B S T R A C T}

This aim of this action research was to improve the ability of elementary school teachers to carry out learning in the classroom through the application of educational supervision. This research was conducted in two cycles and each cycles consisted of 4 stages, namely planning, implementation, observation and reflection. Based on the results of data analysis, it could be seen that there was an improvement on the teachers' ability in implementing the learning process. On the pre cycle, the teachers' ability to carry out the learning process in the classroom was 67.08 with in the level of $67.08 \%$ and it categorized into sufficient. On the first cycle, the teachers' ability to carry out the learning process in the classroom improved to 70.52 with the level of $70.52 \%$ which was categorized into sufficient. On the second cycle, the teachers' ability to carry out the learning process improved again to 77.29 with the level of $77.29 \%$ which was categorized into good category. The teachers'ability to carry out the learning process on the second cycle had exceeded the indicators of success, namely the teacher's ability level of $75 \%$. Based on this, it could be concluded that the application of clinical supervision could improve the teachers' ability of SD Negeri 3 Banjar Tegal in the second semester in the academic year 2019/2020 in classroom learning.

\section{Pendahuluan}

Guru adalah salah satu komponen penting dalam proses pembalajaran, guru berperan untuk menciptakan proses interaksi segala arah antara siswa, guru dan sumber belajar sehingga tujuan pembelajaran terwujud, (Sumiyati, 2017). Proses pembelajaran yang baik adalah pembelajaran yang membuat siswa belajar bukan membuat guru belajar. Belajar aktif adalah berbagai cara membuat siswa aktif melaluiaktivitas-aktivitas yang membangun kerja kelompk dalam membangun pengetahuan tentang materi yang dibelajarankan(Silberman, 2001). Namun kenyataan yang terjadi adalah banyak masih guru-

Copyright (@) Universitas Pendidikan Ganesha. All rights reserved 
guru yang senang lebih akti(Sugeng, 2015) belajar atau dengan kata lain guru masih senang berceramah di depan siswa. Zendrato, 2016 meyatakan bahwa beberpa guru belum menyadiari beberapa aspek yang mempengaruhi proses pembelajaran walupun guru-guru sudah mengikuti seminar tentang bagaimana proses pembelajaran. Hal ini tidak terlepas dari jumlah materi yang harus disampaikan serta tentunya dengan mentranfer pengetahuan segala yang direncanakan oleh guru berasil tepat waktu walaupun hal ini secara tidak langusung mempengaruhi kualitas siswa yang dihasilkan. Pernyataan ini didukung dengan hasil observasi menunjukkna bahwa rata-rata kemampuan guru mengajar sebesar 67,08 dengan tingkat kemampuan guru sebesar $67,08 \%$ yang tergolong cukup. Hal ini terlihat dari Pembelajaran masih terfokus pada guru. Siswa hanya mendengarkan dan melaksanakan perintah guru. Hal ini terjadi karena sangat sulit mengubah gaya mengajar guru. Guru terbiasa dengan pembelajaran konvensional yang sudah dilakukan selama beberapa tahun. Walaupun sudah diberikan pelatihan pembelajaran inovatif, namun ketika melaksanakan proses pembelajaran masih saja terpaku dengan pembelajaran konvensional. Serta hasil diskusi yang dilakukan dengan guru di SD Negeri 3 Banjar Tegal, rendahnya kemampuan guru diakibatkan rendahnya kesadaran guru untuk belajar, kurangnya kesempatan guru mengikuti pelatihan seta baik secara regional maupun nasional, kurang efektifnya PKG, dan supervisi pendidikan yang bertujuan memperbaiki proses pembelajaran cenderung menitik beratkan pada aspek administrasi. Berdasarkan jabaran tersebut guru belum sepenuhnya memiliki wawasan dan merubah pola pikir terhadap proses pembelajaran, serta maslah ini berhubungan dengan kompetensi pedagogi guru dan kompetensi profesional.

Kompetensi pedagogik adalah salah satu kemampuan guru dalam merancang proses pembelajaran yang dapat menghujudkan tujuan pembelajaran yang di programkan. Lubis (2018)menyatakan bahwa kompetensi pedagogik mencakup kemampuan guru dalam mengelola proses pembelajran dan mengembangakan potesi yang dimiliki oleh siswa secara optimal. Senada dengan hal tersebut, Indriani, (2015) menyatakan kompetensi pedagogik adalah kemampuan yang dimiliki oleh guru untuk mengelola pembelajaran dengan pendekatan yang bersifat mendidik peserta didik sehingga pelaksanaan fungsi profesionalnya lebih efektif. Sedangkan Anwar (2019) menyatakan bahwa kemapuan guru dalam mengelola pembelajaran adalah salah satu pembeda profesi guru dibandingkan dengan profesi yang lainnya. Tentunya untuk dapat mengembangkan kompetensi pedagogik guru harus mempunyai kompetensi profesional juga.

Kompetensi profesional adalah kempuan yang dimiliki oleh guru dalam mengelola pengetahuan yang dimilikinya untuk kemajuan dirinya dan tentunya untuk menghasilkan sebuah pendidikan yang berkualitas. Menurut Jamin, (2018) menyatakan kompetensi profesional adalah kemampuan yang hasrus dimiliki oleh guru yang mana mencirikan keprofesionalannya. Guru yangprofesional adalah guru yang mampu mengembangkan kemampuan yang dia miliki. Seperti pernyataan dari Sari, (2017) guru profesional adalah guru yang memiliki kompetensi yang menunjukkan kualitas dalam mengajar. Kompetensi ini terwujud dalam bentuk penguasaan pengetahuan, keterampilan dan profesioanalitas dalam menjalankan tugas. Selain dua kopetensi tersebut guru juga harus memiliki wawasan yang berhubungan dengan mata pelajaran.

Seorang guru dituntut memiliki wawasan yang berhubungan dengan mata pelajaran yang diajarkannya dan wawasan yang berhubungan kependidikan untuk menyampaikan isi pengajaran kepada siswa. Kedua wawasan tersebut merupakan satu kesatuan yang tidak dapat dipisahkan, (Menurut Syamsuddin, 2005). Seorang guru harus selalu meningkatkan kemampuan profesionalnya, pengetahuan, sikap, dan keterampilannya secara terus-menerus sesuai perkembangan ilmu pengetahuan dan teknologi termasuk paradigma baru pendidikan. Seorang guru harus memenuhi tiga standar kompetensi, di antaranya: (1) Kompetensi Pengelolaan Pembelajaran dan Wawasan Kependidikan, (2) Kompetensi Akademik/Vokasional sesuai materi pembelajaran, (3) Pengembangan Profesi. Ketiga kompetensi tersebut bertujuan agar guru bermutu, menjadikan pembelajaran bermutu juga, yang akhirnya meningkatkan mutu pendidikan Indonesia(Syamsuddin, 2005). Untuk mencapai tiga kompetensi tersebut, ada beberapa alternatif yang bisa dilaksanakan yaitu pembinaan terhadap guru baik melalui workshop, PKG, diskusi dan supervisi edukatif. Untuk memperbaiki kemampuan guru SD Negeri 3 Banjar Tegal dalam pembelajaran di kelas, maka dilaksanakan dipilih tindakan dengan menerapkan supervisi edukatif.

Supervisi adalah salah satu bantuan yang diberikan pimpinan kepada guru-guru agar tercapaianya tujuan pendidikan. Supervisi merupakan sebuah proses pelaksaan, penilaian serta koreksi pekerjaan agar tujuan dari yang diprogramkan terlaksana, (Manullang, 2005 dalamPriansa, 2009). Supervisi merupakan pengawasan pelaksanaan kegiatan akademik yang berupa proses belajar pembelajaraan derta proses pengewasan terhadap situasi pendukung proses pembelajaran(Suhardan, 2010). Sedangkan (Astuti, 2017) menyatakan bahwa sepervisi adalah pemberian bimbingan, layanan dan bantuan terhadap gur untuk meningkatkan kualitas pembelajaran agar tujuan belajar siiswa terwujud. Jadi, supervisi adalah 
suatu bantuan yang diberikan terhadap guru untuk meningkatkan kualitas pembelelajaran agar tujuan yang diprogramkan berhasil dilakasankan. Aspek yang disupervisi bisa berupa administrasi, dan edukatif, sedangkan orang yang melakukan supervisi adalah pengawas, kepala sekolah, instruktur mata pelajaran. Adapun orang yang disupervisi bisa kepala sekolah, guru mata pelajaran, guru pembimbing, tenaga edukatif yang lain, tenaga administrasi, dan siswa. Supervisi ada memiliki beberapa jenis. Salah satunya adalah supervisi edukatif.

Supervisi edukatif merupakan supervisi yang diarahkan pada kurikulum pembelajaran, proses belajar mengajar, pelaksanaan bimbingan dan konseling, (Imran, 2018;Desmaini, 2019; Masrayati, 2019). Supervisi ini dapat dilakukan oleh pengawas, kepala sekolah, maupun guru senior yang sudah pernah menjadi instruktur mata pelajaran Pelaksanaan supervisi yang dilakukan oleh kepala sekolah terhadap guru dapat berupa wawancara, observasi, maupun berdasarkan portofolio dalam proses belajar mengajar atau dalam kegiatan bimbingan dan konseling guru (Jokomarsono, 2019). Menurut Dirjen (Dikmenum dalamImran, 2018) observasi tersebut bisa berupa: (1) Observasi kegiatan belajar mengajar meliputi: (a) persiapan mengajar, (b) pelaksanaan satuan pelajaran di dalam kelas, dan (c) pelaksanaan penilaian. (2) Observasi kegiatan Bimbingan dan konseling meliputi: (a) program kegiatan bimbingan dan konseling di sekolah, (b) pelaksanaan bimbingan dan konseling di sekolah, (c) kelengkapan administrasi/ perlengkapan Bimbingan dan Konseling, (d) penilaian dan laporan.

Banyak penelitian tentang supervise edukatif ini dilakukan, beberapa penelitian ini antara lain dilkukan oleh Noor (2018)menyatakan bahwa supervisi teman sejawat dan edukatif kolaboratif dapat meningkatkan kinerja guru dalam menyusun rencana pembelajaran, melaksanakan pembelajaran, menilai prestasi belajar dan tindak lanjut hasil penilaian prestasi belajar siswa. Aqib (2018) menyatakan supervisi edukatif meningkatan kinerja guru dalam menyusun rencana pembelajaran, melaksanakan pembelajaran, menilai prestasi belajar, dan melaksanakan tindak lanjut hasil penilaian prestasi belajar siswa. Mustikeni (2019)menyatakan bahwa penerapan supervisi edukatif Kepala Sekolah memiliki dampak positif dalam meningkatkan kinerja guru. Hal ini dapat dilihat dari semakin mantapnya pemahaman guru dari pembinaan yang diberikan oleh kepala sekolah (rata-rata hasil kinerja guru meningkat dari siklus I, dan II) yaitu dari 66,00 menjadi 82,50. (Chandra, 2018)mennyatakan bahwa terjadinya Peningkatan kinerja guru dalam menyusun rencana pembelajaran, melaksanakan pembelajaran, menilai prestasi belajar, melaksanakan tindak lanjut hasil penilaian prestasi belajar siswa disebabkan dengan penerapan supervisi edukatif. Serta menurut Senayasa (2020) menyatakan bahwa Supervisi Edukatif Kolaboratif secara Periodik dapat meningkatkan Kinerja Guru dalam Pembelajaran di Sekolah Dasar Negeri l Selanbawak tahun pelajaran 2019/2020. Berdasarkan jabaran tersebut dapat dikatakan bahwa supervisi edukatif dapat meningkatkan kinerja guru baik dalam merancang pembelajaran, pelaksaan pembelajaran, penilaian pembelajaran dan melaksanakan tindak lanjut dalam proses pembelajaran.

Berdasarkan hal telah dijabarkan maka dapat dirumuskan tujuan penelitian tindakan sekolah ini adalah untuk meningkatkan kemampuan guru SD Negeri 3 Banjar Tegal semester II tahun pelajaran 2019/2020 dalam melaksanakan pembelajaran di kelas melalui penerapan supervisi edukatif. Dengan dilakukan penelitian tindakan kelas ini diharpakan dapat membantu kualitas kinerja guru di SD N 3 Banjar Tegal.

\section{Metode}

Penelitian tindakan sekolah ini dilaksanakan di SD Negeri 3 Banjar Tegal tempat penulis bertugas sebagai kepala sekolah dilaksanakan pada semester II tahun pelajaran 2019/2020. Subjek penelitian ini adalah guru kelas SD Negeri 3 Banjar Tegal yang jumlahnya 8 orang. Objek penelitian adalah kemampuan guru dalam pembelajaran di kelas. Penelitian ini termasuk penelitian tindakan sekolah dengan empat tahap yaitu perencanaan (planning), pelaksanaan (acting), pengamatan (observing), dan refleksi (reflecting). Penelitian tindakan sekolah bukan saja bertujuan mengumpulkan penyebab dari berbagai permasalahan yang dihadapi, tetapi yang lebih penting lagi adalah memberikan pemecahan masalah berupa tindakan tertentu untuk menungkatkan kualitas proses dan hasil belajar.

Penelitian ini dilakukan dalam dua siklus dan masing-masing siklus terdiri atas: perencanaan, pelaksanaan, observasi dan refleksi. Secara rinci prosedur penelitian mengikuti langkah-langkah sebagai berikut. Pertama, tahap perencanaan diawali dengan melakukan sosialisasi melalui rapat dewan guru untuk pemberitahuan akan tindakan penelitian, menyusun jadwal, merancang RPP, dan instrumen berupa lembar observasi. Kedua, tahap pelaksanaan diawali dengan melakukan diskusi tentang kesulitan yang dialami guru dalam proses pembelajaran dan mencari solusinya. Kemudian dilanjutkan dengan 
melaksanakan observasi di kelas untuk melihat kemampuan guru dalam melaksanakan proses pembelajaran. Setelah observasi selesai dilaksanakan, dilanjutkan dengan pembahasan hasil observasi melalui diskusi kepala sekolah dengan guru. Dilanjutkan dengan menentukan solusi atau pemecahan masalah tentang kekurangan atau hambatan yang ditemui guru dalam melaksanakan proses pembelajaran. Ketiga, tahap observasi terhadap kemampuan guru dalam melaksanakan proses pembelajaran yang dilaksanakan ketika proses pembelajaran berlangsung dengan menggunakan lembar observasi berupa lembar observasi. dan Keempat, tahap refleksi dianalisis hambatan yang dialami pada pelaksanaan kegiatan untuk dicarikan solusinya dan diterapkan pada siklus selanjutnya.

Data yang diperoleh dari hasil observasi berupa kemampuan guru dalam melaksanakan proses pembelajaran di kelas dikumpulkan melalui teknik observasi dengan instrumen lembar observasi. Setelah data dalam penelitian ini terkumpul, selanjutnya dianalisis menggunakan analisis statistik deskriptif, dengan manghitung rata-rata dan rata-rata persen.

Rata-rata kemampuan guru melaksanakan pembelajaran dihitung dengan rumus (1) di bawah ini.

$\mathrm{M}=\frac{\sum \mathrm{X}}{\mathrm{N}}$

(Arikunto, 2015)

Keterangan:

$\mathrm{M} \quad=$ Nilai rata-rata kemampuan guru

$\Sigma \mathrm{X} \quad=$ Jumlah nilai keseluruhan guru

$\mathrm{N} \quad=$ Jumlah seluruh subjek

Adapun rumus yang digunakan untuk menentukan persentase kemampuan guru dalam pembelajaran di kelas ditunjukkan pada rumus (2) berikut.

$$
M(\%)=\left(\frac{M}{S M I}\right) \times 100 \%
$$

(Arikunto, 2015)

Keterangan :

$$
\begin{array}{ll}
\text { M (\%) } & =\text { Rata-rata persen } \\
\text { M } & =\text { Rata-rata skor } \\
\text { SMI } & =\text { Skor maksimal ideal }
\end{array}
$$

Tingkat kemampuan guru dalam pembelajaran di kelasdapat ditentukan dengan membandingkan $\mathrm{M}(\%)$ atau rata-rata persen ke dalam PAP skala lima dengan kriteria pada tabel 1. Penelitian ini dikatakan berhasil apabila kemampuan guru dalam pembelajaran di kelas secara individu telah mencapai rata-rata $\geq 75$, dan tingkat kemampuan guru dalam pembelajaran di kelas sebesar 75\% yang berada pada kategori baik.

Tabel 1. Pedoman Konversi Skala Lima

\begin{tabular}{c|c}
\hline Persentase (\%) & Kriteria \\
\hline $90-100$ & Sangat Baik \\
$75-89$ & Baik \\
$65-74$ & Cukup \\
$40-64$ & Kurang \\
$0-39$ & Sangat Kurang \\
\hline
\end{tabular}

Sumber: Dantes (2009)

\section{Hasil dan pembahasan}

Berdasarkan hasil observasi pada kemampuan guru dalam pembelajaran di kelas pada prasiklus yaitu diperoleh rata-rata sebesar 67,08 dengan persentase skor kemampuan guru dalam pembelajaran di kelassebesar 67,08\% yang dikonvesikan ke dalam PAP skala lima, berada pada tingkat penguasaan 65$74 \%$ yang berarti bahwa kemampuan guru dalam pembelajaran di kelas pada prasiklus tergolong cukup. 
Pada siklus I tahap perencanaan disiapkan intrumen validasi yang akan digunakan untuk menilai kemampuan guru di dalam kelas. Tahap pelaksanaan berlangsung sebanyak 3 kali pertemuan. Pertemuan pertama menentukan jadwal kegiatan. Pertemuan kedua peneliti melakukan observasi pelaksanaan proses pembelajaran yang dilaksanakan guru, dengan pengaturan tiap pertemuan 1 orang guru. Pertemuan ketiga berdiskusi dengan guru untuk membahas kelebihan dan kekurangan kemampuan guru di dalam kelas berdasarkan hasil observasi. Berdasarkan hasil observasi diperoleh rata-rata kemampuan guru di dalam kelas sebesar 70,52 dengan persentase skor kemampuan guru dalam pembelajaran di kelas sebesar 70,52\% yang dikonvesikan ke dalam PAP skala lima, berada pada tingkat penguasaan $65-74 \%$ yang berarti bahwa kemampuan guru dalam pembelajaran di kelas pada siklus I tergolong cukup. Berdasarkan hasil analisis data diperoleh peningkatan kemampuan guru SD Negeri 3 Banjar Tegal di dalam kelas, Hal ini disebabkan karena pelaksanaan supervisi edukatif. Tugas utama kepala sekolah adalah melakukan pengawasan dan bimbingan kepada guru terkait kemampuan guru khususnya proses pembelajaran yang dilakukan oleh guru yang akan berpengaruh pada peningkatan hasil belajar siswa. Melalui supervisi edukatif guru diobservasi oleh kepala sekolah, kemudian hasil observasi didiskusikan bersama untuk mengatasi kelemahan atau kesulitan yang dialami oleh guru.

Beberapa kendala ditemukan pada siklus I yaitu guru kurang inovatif dalam memilih metode pembelajaran, buku sumber, dan media pembelajaran.Hal ini diatasi dengan memberikan pemahaman yang lebih mendalam tentang pemilihan metode pembelajaran, buku sumber, dan media pembelajaran. Dalam proses pembelajaran guru masih tampak canggung, karena merasa diawasi dan takut salah. Hal ini diatasi dengan memberikan pemahaman bahwa supervisi yang dilakukan bukan mencari-cari kesalahan guru, tetapi menemukan kekurangan agar bisa diperbaiki. Dalam mengemukakan pendapat atau kendala yang dihadapi, guru masih ragu-ragu karena merasa adanya perbedaan jabatan.Hal ini diatasi dengan mengupayakan suasana yang kondusif sehingga bisa terjadi komunikasi yang baik.Semua kendala itu diupayakan dapat diminimalisasi pada pelaksanaan siklus II.

Pada siklus II tahap perencanaan disiapkan intrumen validasi kemampuan guru di dalam kelas dalam melaksanakan proses pembelajaran. Tahap pelaksanaan berlangsung sebanyak 3 kali pertemuan.Pertemuan pertama menentukan jadwal kegiatan. Pertemuan kedua peneliti melakukan observasi pelaksanaan proses pembelajaran yang dilaksanakan guru, dengan pengaturan tiap pertemuan 1 orang guru. Pertemuan ketiga berdiskusi dengan guru untuk membahas kelebihan dan kekurangan kemampuan guru di dalam kelas. Berdasarkan hasil observasi diperoleh rata-rata kemampuan guru di dalam kelas sebesar 77,29 dengan persentase skor kemampuan guru dalam pembelajaran di kelas sebesar 77,29\% yang dikonvesikan ke dalam PAP skala lima, berada pada tingkat penguasaan $75-89 \%$ yang berarti bahwa kemampuan guru dalam pembelajaran di kelas pada siklus II tergolong baik. Berdasarkan hasil analisis data diperoleh peningkatan kemampuan guru SD Negeri 3 Banjar Tegal dalam pembelajaran di kelas. Hal ini disebabkan karena pelaksanaan supervisi edukatif dengan mengatasi kendala atau hambatan yang ditemui pada siklus I. Karena hasil penelitian telah melampaui indikator keberhasilan maka penelitian dihentikan pada siklus II. Hasil penelitian dari prasiklus dampai dengan siklus II dijabarkan pada tabel 2 berikut.

Tabel 2. Rekap Hasil Penelitian

\begin{tabular}{c|c|c}
\hline Siklus & M & M\% \\
\hline Pra & 67,08 & 67,08 (Cukup) \\
I & 70,52 & 70,52 (Cukup) \\
II & 77,29 & 77,29 (Baik) \\
\hline
\end{tabular}

Berdasarkan data pada tabel 2 di atas terlihat bahawa ada peningkatan kemampuan guru dalam pembelajaran kelas yaitu dari siklus pra rata-rata $=67,08$ meningkat menjadi $70,52 \%$ pada siklus I dan meningkat lagi menjadi $77,29 \%$ pada siklus II. Hal ini disebabkan karena penerapan supervisi edukatif yang dapat berjalan dengan optimal. 


\section{Pembahasan}

Bersarkan hasil penelitian yang sudah dijabarkan sebelumnya dapat dikatakan bahwa terjadi peningkatan kinerja guru dari prasiklus, Siklus I dan Siklus IIsetelah diberikan tindakan Supervisi edukatif. Dengan dilaksankan Supervisi edukukatif ini guru dapat menyiapkan proses pembelajaran dengan baik sebab kendala-kendala yang dihadapi dapat dipecahkan dari bimbingan yang dilakukan oleh pimpiman baik pengawas dan kepala sekolah. Dengan adanya diskusi maka akan membantu guru untuk menyampaikan apa yang menjadi kendala yang dihadapi dalam melaksankan kurikulum yang di programkan. Terjadinya peningkatan kinerja guru ini tidak terlepas dari Supervisi yang dilkukan.

Supervisi adalah salah satu bantuan yang diberikan pimpinan kepada guru-guru agar tercapaianya tujuan pendidikan. Supervisi merupakan sebuah proses pelaksaan, penilaian serta koreksi pekerjaan agar tujuan dari yang diprogramkan terlaksana, (Manullang, 2005 dalamPriansa, 2009). Supervisi merupakan pengawasan pelaksanaan kegiatan akademik yang berupa proses belajar pembelajaraan derta proses pengewasan terhadap situasi pendukung proses pembelajaran (Suhardan, 2010). Sedangkan Astuti, (2017) menyatakan bahwa sepervisi adalah pemberian bimbingan, layanan dan bantuan terhadap gur untuk meningkatkan kualitas pembelajaran agar tujuan belajar siiswa terwujud. Jadi, supervisi adalah suatu bantuan yang diberikan terhadap guru untuk meningkatkan kualitas pembelelajaran agar tujuan yang diprogramkan berhasil dilakasankan. Aspek yang disupervisi bisa berupa administrasi, dan edukatif, sedangkan orang yang melakukan supervisi adalah pengawas, kepala sekolah, instruktur mata pelajaran. Adapun orang yang disupervisi bisa kepala sekolah, guru mata pelajaran, guru pembimbing, tenaga edukatif yang lain, tenaga administrasi, dan siswa. Supervisi ada memiliki beberapa jenis. Salah satunya adalah supervisi edukatif.

Supervisi edukatif merupakan supervisi yang diarahkan pada kurikulum pembelajaran, proses belajar mengajar, pelaksanaan bimbingan dan konseling, (Imran, 2018;Desmaini, 2019; Masrayati, 2019). Supervisi ini dapat dilakukan oleh pengawas, kepala sekolah, maupun guru senior yang sudah pernah menjadi instruktur mata pelajaran Pelaksanaan supervisi yang dilakukan oleh kepala sekolah terhadap guru dapat berupa wawancara, observasi, maupun berdasarkan portofolio dalam proses belajar mengajar atau dalam kegiatan bimbingan dan konseling guru(Jokomarsono, 2019). Menurut Dirjen Dikmenum (1884:16) dalam Imran (2018)observasi tersebut bisa berupa: (1) Observasi kegiatan belajar mengajar meliputi: (a) persiapan mengajar, (b) pelaksanaan satuan pelajaran di dalam kelas, dan (c) pelaksanaan penilaian. (2) Observasi kegiatan Bimbingan dan konseling meliputi: (a) program kegiatan bimbingan dan konseling di sekolah, (b) pelaksanaan bimbingan dan konseling di sekolah, (c) kelengkapan administrasi/ perlengkapan Bimbingan dan Konseling, (d) penilaian dan laporan.

Pertama. Dengan adanya supervisi edukatif ini akan meumbuhkan pengaruhpositif terhadap perbaikan kualitas kinerja guru. Kinerja guru adalah tingkat ketercapainnya tujuan yang sudah diprogra/ keberhasilan yang diperoleh oleh guru dalam mencapai tujuan pembelajaran. kinerja adalah peningkatan pencapain seseorang dalam waktu tertentu (Moeheriono, 2009 dalam Rasto, 2016). Kinerja guru memiliki spesifikasi tertentu, serta dapat diukur dengan indicator tertentu. Menurut Uno dan Lamatenggo, 2012 dalam Rasto, (2016) merumuskan lima indicator untik mengukur kinerja guru yaitu Pertama, Kualitas kerja. Indikator ini berkaitan dengan kualitas kerja guru dalam menguasai segala sesuatu berkaitan dengan persiapan perencanaan program pembelajaran dan penerapan hasil penelitian dalam pembelajaran di kelas. Kedua, Ketetapan kerja. Indikator ini berkaitan dengan ketepatan kerja guru dalam menyesuaikan materi ajar dengan karakteristik yang dimiliki peserta didik dan penyelesaian program pengajaran sesuai dengan kalender akademik. Ketiga, Inisiatif dalam kerja. Indikator ini berkaitan dengan inisiatif guru dalam penggunaan model pembelajaran yang variatif sesuai materi pelajaran dan penggunaan berbagai inventaris sekolah dengan bijak. Keempat, Kemampuan kerja. Indikator ini berkaitan dengan kemampuan guru dalam memimpin keadaan kelas agar tetap kondusif, pengelolaan kegiatan belajar mengajar, dan penilaian hasil belajar peserta didik. Dan Kelima, Komunikasi. Indikator ini berkaitan dengan komunikasi yang dilakukan guru dalam proses layanan bimbingan belajar dengan siswa yang kurang mampu mengikuti pembelajaran dan terbuka dalam menerima masukan untuk perbaikan pembelajaran. Tercapainya kinerja guru yang baik tidak terlepas dari faktor-faktor tertentu. Faktor-faktor tersebut antara lain faktor dari diri guru yaitu faktor kemapuan serta faktor pendorong (motivasi) yang diterima dari oaring-orang yang ada disekitarnya. Mangkunegara (2004)menyatakan bahwa faktor yang mempengaruhi kinerja guru adalah kemanpuan dan motivasi. Kemapuan berkaitan dengan apa yang dimiliki oleh guru baik potensi guru (IQ) dan kemapuan pengalaman baik keterampilan dan pengetahuan. Sedangkan motivasi adalah sikpa guru dalam menghadapi situasi kerja, sikap ini beruapa semangat kerja, dorongan yang dimiliki oleh guru untuk menyelesaikan proses pembelajaran 
yang berkualitas sehingga tujuan dari pembelajaran itu diperoleh. Dengan adanya faktor-faktor ini akan berpengaruh terhadap keberhasilan kinerja guru.

Kedua, dengan adanya supervisi edukatif ini guru akan mendapatkan arahan, bimbingan dan konseling dari pihak-pihak seperti pengawas dan kepala sekolah. Arahan, bimbingan dan konseling yang diberikan oleh kepala sekolah terhadap proses pembelajaran dapat membatu guru memperbaiki proses pembejaran hal ini sesuia dengan tujuan supervisi Depdikbud, 1995 dalam Handayani, 2018 meyatakan tujuan supervise adalah mengembangkan proses pembelajaran yang lebih baik melalui pembinaan dan peningkatan professional guru di dalam mencapi tujuan pembelajaran yang sesaui dengan program yang diberikan. Selain itu tujuan Supervisi menurut Sukatin, 2016 (dalam Ilham, 2017)adalah perbaikan dan pengembnagan proses pembelajaran secara total bukan hanya mutu mengajar guru tetapi juga untuk membina dan menumbukan profesi guru seperti pengadaan sumber belajar. Selain itu tujuan Suvervisi adalah peningkatan kinerja dari seluruh komponen sekolah agar mampu menumbuhkan dan mengbangkan keungulan bersaing. (Baharudin, 2016 dalam Ilham, 2017). Jadi dengan adanya supervise akan membantu guru untuk lebih termotivasi dalam memperbaiki proses pembelajaran. hasil penelitian ini didukung oleh beberapa penelitian.

Penelitian itu antara lain Noor (2018)menyatakan bahwa supervisi teman sejawat dan edukatif kolaboratif dapat meningkatkan kinerja guru dalam menyusun rencana pembelajaran, melaksanakan pembelajaran, menilai prestasi belajar dan tindak lanjut hasil penilaian prestasi belajar siswa. Aqib (2018) menyatakan supervisi edukatif meningkatan kinerja guru dalam menyusun rencana pembelajaran, melaksanakan pembelajaran, menilai prestasi belajar, dan melaksanakan tindak lanjut hasil penilaian prestasi belajar siswa. Mustikeni (2019) menyatakan bahwa penerapan supervisi edukatif Kepala Sekolah memiliki dampak positif dalam meningkatkan kinerja guru. Hal ini dapat dilihat dari semakin mantapnya pemahaman guru dari pembinaan yang diberikan oleh kepala sekolah (rata-rata hasil kinerja guru meningkat dari siklus I, dan II) yaitu dari 66,00 menjadi 82,50. Chandra (2018)mennyatakan bahwa terjadinya Peningkatan kinerja guru dalam menyusun rencana pembelajaran, melaksanakan pembelajaran, menilai prestasi belajar, melaksanakan tindak lanjut hasil penilaian prestasi belajar siswa disebabkan dengan penerapan supervisi edukatif. Serta menurut Senayasa (2020)menyatakan bahwa Supervisi Edukatif Kolaboratif secara Periodik dapat meningkatkan Kinerja Guru dalam Pembelajaran di Sekolah Dasar Negeri I Selanbawak tahun pelajaran 2019/2020. Berdasarkan jabaran tersebut Supervisi edukatif dapat meningkatkan kinerja guru. Karena dengan adanya supervise dapat meningkatkan kemapuan guru dalam memperbaiki kualitas pembelajaran. Arahan dan bimbingan dari guru akan membantu guru untuk mempunyai motivasi dalam menyelesaikan malalah yang dihaspi dalam prose pembelajaran.

\section{Simpulan dan saran}

Dari penelitian yang dilakukan dapat disimpulkan bahwa penerapan supervisi edukatif dapat meningkatkan kemampuan guru SD Negeri 3 Banjar Tegal semester II tahun pelajaran 2019/2020 dalam pembelajaran di kelas. Hal ini terlihat dari tingkat kemampuan guru pada prasiklus sebesar 67,08\% yang tergolong cukup, meningkat pada siklus I menjadi 70,52\% yang tergolong cukup, dan meningkat lagi pada siklus II menjadi 77,29\% yang tergolong baik. Berdasarkan hasil analisis data diperoleh peningkatan kemampuan guru SD Negeri 3 Banjar Tegal dalam pembelajaran di kelas.

Adapun saran yang dapat disampaikan berdasarkan proses dan hasil penelitian ini yaitu: Bagi guru, hasil penelitian ini dapat digunakan oleh guru dalam melakukan perbaikan proses pembelajaran. Bagi Kepala Sekolah, kepala sekolah hendaknya selalu memberikan anjuran kepada guru dalam memulai proses pembelajaran hendaknya dipersiapkan dulu rencana pelaksanaan pembelajaran (RPP) agar proses pembelajaran berjalan secara efektif dan efisien. Selain itu kepala sekolah hendaknya mampu mengembangkan berbagai kebijakan sekolah dalam rangka pengembangan manajemen berbasis sekolah dan sekaligus sebagai media strategis dalam menjalin kemitraan yang mutualis antara sekolah dengan pihak lain, dalam upaya melakukan berbagai inovasi dan perbaikan-perbaikan kualitas guru, serta peningkatan profesionalisme staf (guru) di sekolahnya. Bagi Dinas Pendidikan , hendaknya mampu mengambil kebijakan pendidikan, khususnya berkait dengan pemberdayaan guru, serta turut memberi kontribusi dalam rangka peningkatan kualitas profesionalisme guru-guru pemegang mata pelajaran, sehingga mereka nantinya dapat menjadi tenaga pendidik yang berkualitas dan profesional di bidangnya. 


\section{Daftar Rujukan}

Anwar, B. (2019). Kompetensi Pedagogik Sebagai Agen Pemebelajaran. Shaul Al-'Arabiyah, 114-125.

Aqib, Z. (2018). Peningkatan Kinerja Guru Melalui Supervisi Edukatif Kolaboratif Secara Periodik di SDN Lamongrejo 4 Ngimbang Lamongan. Jurnal Pendidikan Islam, 4(1), 83-90.

Arikunto, S. (2015). Dasar-dasar Evaluasi Pendidikan. Jakarta: Bumi Aksara.

Astuti, S. (2017). Supervisi Akademik Untuk Meningkatkan Kompetensi Guru di SD Laboratorium UKSW. Scholaria, 7(1), 49-59.

Chandra, S. (2018). Meningkatnya Kinerja Guru dalam Pembelajaran di Kelas Melalui Supervisi Edukatif Kolaboratif Secara Sistematis dan Terjadwal. Jurnal Pendidikan Tambusai, 2(6), 2001-2017.

Desmaini. (2019). Supervisi Edukatif Kolaboratif Secara Periodik untuk Meningkatkan Kinerja Guru Dalam Pembelajaran di Kelas. Journal Education Of Batanghari, 1(1), 1-21.

Ilham, W. (2017). Supervisi Pendidikan dalam Perspektif Epistemologi Islam. Jurnal Pedagogik, 4(1), 2946.

Imran. (2018). Peningkatan Kinerja Guru Melalui Supervisi Edukatif Kolaboratif Secara Periodik Di SMA Negeri 1 Malgano Kabupaten Muna Tahun 2014. Jurnal Gema Pendidikan, 25(2), 1-10.

Indriani, F. (2015). Kompetensi Pedagogik Guru dalam Mengelola Pembelajaran IPA di SD dan MI. FENOMENA, 7(1), 17-28.

Jamin, H. (2018). Upaya Meningkatkan Kompetensi Profesional Guru. Jurnal Ilmiah Pendidikan Agama Islam, 10(1), 19-36.

Jokomarsono, W. (2019). Supervisi Edukatif Kolaboratif Secara Periodik Sebagai Upaya Peningkatan Kinerja Guru Dalam Pembelajaran. Jurnal Dinamika Manajemen Pendidikan, 4(1), 42-59.

Lubis, H. (2018). Kompetensi Pedagogik Guru Pofesional. Best Journal, 1(2), 16-19.

Mangkunegara, A. A. P. (2004). Manajemen Sumber Daya Manusia. Bandung: Remaja Rosdakarya.

Masrayati. (2019). Peningkatan Kinerja Guru dalam Pembelajaran di Kelas Melalui Supervisi Edukatif Kolaboratif Secaa Periodik Tahun2017. Jurnal Education and Development Institut Pendidikan Tapaluni Selatan, 7(4), 206-209.

Mustikeni. (2019). Peningkatan Kinerja Guru Melalui Supevisi Edukatif Kolaboratif di SDN 2 Setanggor. Jurnal Eduasi Dan Sains, 1(2), 310-321.

Noor, M. (2018). Peningkatan Kinerja Guru Melalui Supervisi Edukatif Kolaboratif Secara Periodik. Jurnal Ilmiah Pendidikan Guru Madrasah Ibtidaiyah, 8(1), 45-60.

Priansa, D. J. (2009). Manajemen Supervisi \& Kepemimpinan Kepala Sekolah. Bandung: Alfabeta.

Rasto, K. dan. (2016). Kompetensi dan Kinerja Guru Berdasaran Sertifikasi Profesi. Jurnal Pendidikan Manajemen Perkantoran, 1(1), 61-71.

Senayasa, I. M. (2020). Supervisi Eduatif Kolaboratif Secara Periodik Untuk Meningkatkan Kinerja Guru Di SD Negeri 1 Selanbawak. Widyadari, 21(1), 351-363.

Silberman, M. (2001). Active Learning 101 Strategi Pembelajaran Aktif. Yogyakarta: YAPPENDIS.

Sugeng, M. (2015). Komponen Silabus, Komponen RPP, dan Prinsip Penyusunan RPP Pada Implementasi Kurikulum 2013. Retrieved February 23, 2019, from https://www.salamedukasi.com/2014/07/ komponen-silabus-komponen-rpp-dan.html

Suhardan, D. (2010). Supervisi Profesional. Bandung: Alfabeta.

Sumiyati, E. (2017). Penggunaan Model Pembelajaran Interaktif Berbasis Aktivitas Untuk Meningkatkan Prestasi Belajar Siswa Kelas VI Pada Pelajaran PKN SD Negeri 09 Kabawetan. Jurnal Ilmiah Pendidikan Guru Sekolah Dasar, 10(2), 66-72.

Syamsuddin, A. (2005). Psikologi Pendidikan. Bandung: PT Remaja Rosdakarya. 